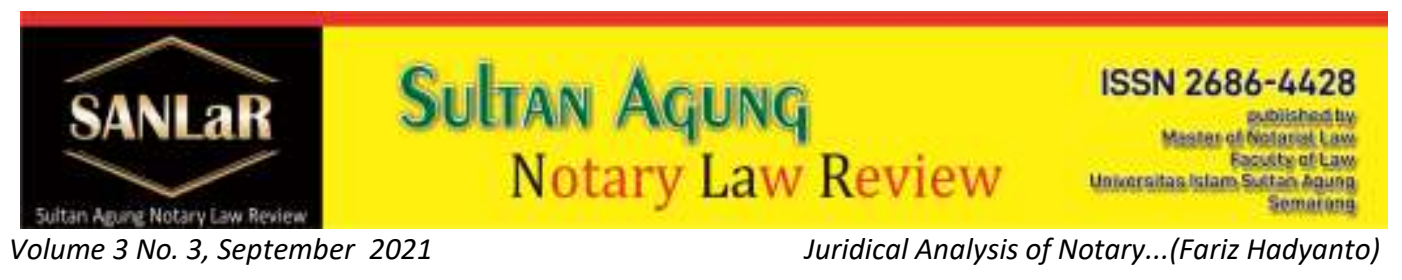

\title{
Juridical Analysis of Notary Responsibilities Relating to Deed of Sale and Purchase Binding Agreement (PPJB) that Causes Disputes
}

\author{
Fariz Hadyanto*) \\ ${ }^{*}$ Faculty of Law, Universitas Islam Sultan Agung (UNISSULA) Semarang, E-mail: \\ farizhd@gmail.com
}

\begin{abstract}
The purpose of this research is to analyze and find out: 1). The Notary's responsibility in making the sale and purchase binding agreement (PPJB) that he made. 2). The solution to the making of the sale and purchase binding agreement (PPJB) in the event of a dispute. The approach method in this research is normative juridical. The data used are primary and secondary data obtained through interviews and literature study, data analysis was carried out by analytical descriptive. The results of the research concluded: 1). The Notary's responsibility in making the sale and purchase binding agreement (PPJB) that he made is if the sale and purchase agreement on land signed and made by a Notary made an error, it is not in accordance with the procedure for making it, then the Notary has legal responsibility to whom and to whom. who the deed of sale and purchase agreement is made, and if the Notary is proven to have made a mistake, whether intentional or unintentional, then the legal consequences that arise can be subject to sanctions according to the level of error or error in the binding deed of sale and purchase made by a Notary may be subject to sanctions including administrative sanctions 2). The solution to making a deed of sale and purchase binding agreement (PPJB) in the event of a dispute is through deliberation or through the courts. The aggrieved party can sue the party who caused the loss in court or by canceling the agreement that has been made by the parties. Dispute resolution using non-litigation or Alternative Dispute Resolution (ADR) is actually a family dispute resolution model compared to dispute resolution through judicial institutions which tend to be confrontational, taking into account wins and losses and ignores social elements in society. While the settlement through the judiciary is carried out if the deliberation efforts are not reached, then the settlement must be through the courts.
\end{abstract}

Keywords: Notary; Responsibilities; PPJB; Disputes. 


\section{Introduction}

The sale and purchase agreement is an agreement that is most commonly held among members of the community. The form of a sale and purchase agreement is a series of rights and obligations of the two parties who promise each other, namely the seller and the buyer. Based on the Civil Code Article 1457, buying and selling includes an agreement where the party who owns the land is called the "seller", promises and binds himself to surrender his rights to the land in question to another party called the "buyer". The binding sale and purchase agreement according to R. Subekti is: ${ }^{1}$

The deed of sale and purchase agreement made before a Notary is a binding sale and purchase agreement on land objects made between the prospective seller and the prospective buyer prior to the signing of the Sale and Purchase Deed (AJB). The binding sale and purchase agreement on land that is certified as property rights can be carried out before a Notary, while the making of a sale and purchase deed must be carried out in the presence of a Land Deed Making Officer (PPAT). After the seller and buyer submit the land certificate, proof of tax deposit and identity documents of the parties and pay the transaction fee components, the seller and buyer go to PPAT to sign the Sale and Purchase Deed (AJB).

Article 19 of Act No. 5 of 1960 stipulates that the sale and purchase of land must be proven by a deed made before the Land Deed Making Official (PPAT). So the sale and purchase of rights to land and or buildings must be carried out before the PPAT. This is as evidence that there has been a sale and purchase of land rights and then the PPAT makes a deed of sale and purchase. ${ }^{2}$

The Sale and Purchase Binding Agreement (PPJB) is made to carry out a temporary binding before the official Sale and Purchase Deed (AJB) is made before the PPAT. The meaning and function of the sale and purchase binding agreement (PPJB) made before a Notary is actually no different from the agreement in general. The binding of the Sale and Purchase Agreement is made under the hand due to a certain reason such as the payment of the price has not been paid off. It's just that the binding sale and purchase agreement is an agreement that was born due to the open nature of Book III of the Civil Code, which provides the widest freedom for legal subjects to enter into agreements containing anything and in any form, as long as does not violate statutory regulations.

\footnotetext{
${ }^{1}$ Subekti, 1998,Hukum Perjanjian,Intermasa, Jakarta, p. 75

Ilbid, p. 95
} 
The sale and purchase binding agreement was born as a result of the obstruction or the presence of several requirements determined by the law relating to the sale and purchase of land rights which ultimately hampered the completion of transactions in the sale and purchase of land rights. over the ground. The requirement is that there is an agreement between the parties who will carry out the sale and purchase of land rights, requirements arising from the Act, for example the sale and purchase must have been paid off before the sale and purchase deed (AJB) can be signed. In general, the requirements that often arise are requirements that are agreed upon by the parties who will make a sale and purchase. The buyer wants a certificate of land rights to be purchased while the rights to the land to be sold do not yet have a certificate. and on the other hand, for example, the buyer has not been able to pay all the prices of land rights in full, so that only half of the agreed price has been paid. With this situation, of course, it will hinder the making of the deed of sale and purchase, because the official making the land deed will refuse to make the deed of sale because all the requirements have not been completed.

\section{Research Methods}

The approach method used in this study is a normative juridical approach. Primary and secondary data sources obtained by interview method and literature review (study document). The data that has been collected both from field research and library research were analyzed using descriptive analysis methods.

\section{Results and Discussion}

\subsection{The Notary's Responsibility in Making the Sale and Purchase Binding Agreement (PPJB) he made}

The more advanced a region encourages the high number of buying and selling, especially buying and selling land, buildings, property and others. This is what causes a high level of need for Notaries. This increase is in line with the importance of the Notary's accountability in the Making of Sale and Purchase Deeds. Notary responsibilities are very important for the realization of legal protection for the community. Sale and purchase according to the Civil Code is an agreement in which one party (the seller) binds himself to surrender (ownership rights to) an object and the other party (the buyer) pays the promised price in accordance with Article 1457.

The Sale and Purchase Binding Agreement which is often called PPJB is, to reaffirm the parties as a result of the Notary's proposal, the thing that the Notary proposes is regarding the form of a temporary deed, namely in the form of a binding agreement, the Notary as a public official who pours the agreement in the form of the deed. Actually, without any binding words, the parties are 
already bound by a sale and purchase agreement. The effect of the word binding is only to convince the parties to the agreement, because now almost all deed of sale and purchase agreements are entitled PPJB. Because PPJB contains certain conditions in the binding, namely a prior agreement to be mutually agreed between the parties in the legal event. ${ }^{3}$

The sale and purchase binding agreement (PPJB) was born as a result of delays or the presence of several requirements relating to the sale and purchase of land rights that have not been fulfilled, so that it is not possible for an authentic deed of sale and purchase before the official making the land deed. As for the requirements that have not been met, such as sales and purchase taxes that have not been paid by each seller and buyer or the certificate on which the land rights are based, there is still a record of the imposition of mortgage rights that must be paid, before the deed of sale and purchase can be signed before the official making the land deed. The sale and purchase binding agreement is actually no different from the agreement in general. ${ }^{4}$

Based on chapter 1 point 1 of Act No. 30 of 2004 concerning the Position of a Notary as amended by Act No. 2 of 2014, states that a Notary is a public official who is authorized to make an authentic deed and has other authorities as referred to in this law or based on the law other laws. Through the notary understanding, it can be seen that the task of a notary is a public official, while his authority is mainly to make an authentic deed. ${ }^{5}$ The position of the Notary as a public official in the sense that the authority granted by the state to the Notary is never given to other officials, as long as the authority is not the authority of other officials in making authentic deeds, then the authority becomes the authority of the Notary. ${ }^{6}$

In his explanation, Article 2 of the UUJN states that a Notary is appointed and dismissed by the minister (government), in this case the minister who is given the task and responsibility includes the Notary field (Article 1 point 14 UUJN). Even though a Notary is administratively appointed and dismissed by the

\footnotetext{
${ }^{3}$ Dewi Kurnia Putri, Amin Purnawan, Perbedaan Perjanjian Pengikatan Jual Beli Lunas dengan Perjanjian Pengikatan Jual Beli Tidak Lunas, Jurnal Akta, Vol.4 Nomor 4 December 2017, p. 626

${ }^{4}$ Herlina Hasibuan, Analisis Yuridis Penolakan Pembatalan Akta Perjanjian Pengikatan Jual Beli (Ppjb) Hak Atas Tanah Melalui Prosedur Gugatan Ke Pengadilan (Studi Putusan MA No. 3703.K/Pdt/2016), Tesis Fakultas Hukum Universitas Sumatera Utara Medan, 2020, p.36

${ }^{5}$ Wiriya Adhy Utama dan Ghansham Anand, Perlindungan Hukum Terhadap Notaris Pengganti Dalam Pemanggilan Berkaitan dengan Kepentingan Peradilan, Jurnal Panorama Hukum, Volume 3 No.1 - 2018 ISSN : 22664, p. 106

${ }^{6}$ Deviana Yuanitasari, The Role of Public Notary in Providing Legal Protection on Standard Contracts for Indonesian Consumers, Sriwijaya Law Review Journal, Vol. 1 Nomor 2 July 2017, p.179.
} 
government, it does not mean that a Notary is subordinate to the person who appointed him or her. ${ }^{7}$

In Article 22 of the UUJN it is emphasized that the formation of a Notary position is determined based on the activities of the business world, the population and the average number of deeds drawn up by and/or before a Notary every month. ${ }^{8}$ Habib Adjie put forward three benefits of notarial deed or authentic deed, which include:

a. For the parties who make an agreement in a notarial deed, it is to get certain legal certainty from what is written in the notarial deed.

b. Provide a sense of security for the parties who make the agreement because if one party feels aggrieved by the other party, then, the party who feels aggrieved can sue based on the notarial deed.

c. In terms of proof, a notarial deed has perfect proof. The perfection of a notarial deed as evidence, it must be seen as it is, it is not necessary or assessed or interpreted differently, other than what is written in the deed. ${ }^{9}$

The Notary's responsibilities in making the sale and purchase binding agreement (PPJB) that he made are: ${ }^{10}$

1. The notary's civil liability for the material truth in the deed he made

The notary is responsible civilly for the material truth in the deed he made. Notaries have the authority to provide services to the community or people who need their services in making a deed, but the contents of the deed contain things that are contrary to the law, causing harm to others, while the parties who are present before the Notary know that what is stated in the deed according to the interests of the parties, and can be accounted for because the Notary is negligent in stating what is not based on the existing facts. However, according to Sudikno Mertokusumo, the Notary in making the deed must record what is stated by the interested parties and is not required to check the truth of the material contents. In the practical world, a Notary may be negligent in the contents of the deed because of incorrect information, whether intentionally or not, from the parties. Actually, the error cannot be held accountable by the Notary because the contents of the deed have been confirmed to the parties and have been justified

\footnotetext{
${ }^{7}$ Soegianto, 2015, Etika Profesi dan Perlindungan Hukum Bagi Notaris, Farisma Indonesia, Yogyakarta, p. 13

${ }^{8}$ Habib Adjie, 2008, Hukum Notaris Indonesia, Refika Aditama, Bandung, p.49

${ }^{9}$ Habib Adjie, 2008, Sanksi Perdata dan Administratif Terhadap Notaris sebagai Pejabat Publik, Refika Aditarna, Bandung, p. 49.

${ }^{10}$ Ibid.
} 
by the interested parties for the contents read out before the parties. ${ }^{11}$ The explanation of the UUJN shows that the Notary is only responsible for the formality of an authentic deed and not for the material content of the deed. However, a Notary can be held accountable for the material truth of a deed if the legal advice he gives turns out to be wrong. In fact, in the Notary profession, with an attitude of carelessness and seriousness carried out in carrying out the duties and authority of a Notary, the Notary actually has brought himself to actions regulated by law and must be accountable. A Notary's fault can be proven, then a Notary can be charged with sanctions, which can be in the form of threats that have been determined in the law.

\section{Notary Accountability based on UUJN}

The responsibility under the Notary Position Act (UUJN) for the material truth in the deed he made is related to the Indonesian Notary profession. So, Act No. 30 of 2004 in conjunction with Act No. 2 of 2014 concerning Notary Positions is a regulation regarding Indonesian Notaries. UUJN of course explicitly stipulates the responsibilities of a Notary in Article 65 of the UUJN that the Notary is responsible for the authentic deed he made even though the Notary protocol has been transferred to the Notary protocol custodian. If the provisions indicate that the Notary is formally responsible for the validity of the authentic deed he made and it turns out to contain a legal defect, namely a juridical defect so that the deed loses its authenticity and is detrimental to the interested parties, the Notary can be sued for reimbursement, compensation and interest. UUJN actually regulates more formal requirements that must be carried out by a Notary and if there is a lack of understanding or negligence in fulfilling the formal requirements in making an authentic deed, it can be held accountable.

Regarding the material responsibility for the deed made before a Notary, it is necessary to emphasize that with the authority of the Notary in making an authentic deed, and the authentic deed is the deeds of the interested parties, not the deed of the Notary concerned. In fact, it is true that there are often disputes over agreements, which are contained in a Notary deed consisting of interested parties and made before a Notary, so actually those who are bound are those who enter into the agreement itself, while the Notary is not bound to fulfill any promises or obligations as stated in the agreement. PPJB and Notaries are completely outside the scope of those who are parties.

3. The Notary's responsibility in carrying out his/her duties is based on the Notary's code of ethics.

\footnotetext{
${ }^{11}$ Sudikono Mertokusumo, 1998, Hukum Acara Perdata Indonesia, Liberty, Yogyakarta , p.149
} 
Notary profession is a profession related to society in general, related to individual professional organizations and the state. The actions of a notary will be related to these elements, so a notary's actions that are wrong in carrying out his work will harm himself and professional organizations, society and the state. The Notary's relationship with the community and the state is regulated in the UUJN. Meanwhile, the relationship between a Notary and a Notary professional organization is regulated in the Notary's code of ethics. Notaries are public officials who are entrusted with and must adhere not only to the laws and regulations but also to the professional code of ethics because without a code of ethics, the dignity of the profession will be lost.

In relation to the responsibilities of a Notary, the Notary's code of ethics has a relationship with the UUJN which requires a Notary in carrying out his/her job duties to always comply with the UUJN must also comply with the professional code of ethics and must be responsible for the community he serves, professional organizations (Indonesian Notary Association or INI) as well as to the state. With this relationship, a Notary who ignores the nobility of the dignity of his position in addition to being subject to sanctions, reprimanded or dismissed from his professional membership and also dismissed from his position as a Notary. Violations related to the Notary's code of ethics are actions by members of the Indonesian Notary Association or other people who carry out the position of a Notary who violate the provisions of the code of ethics and or organizational discipline.

Notary in carrying out his duties: ${ }^{12}$

a. In making a deed, a Notary is required to make a deed properly and correctly, meaning that the deed made is based on the will of the interested parties and the will of the law.

b. In making a deed, a notary is required to make a quality deed. This means that the deed he made must be based on the will of the interested parties and in accordance with the rule of law, not making it up.

c. The deed made by the Notary must have a positive impact on the parties present before him. This means that the public recognizes that the notary deed has the power of perfect and authentic evidence.

To guarantee the legal certainty of buying and selling land that still requires action According to other laws, generally the sale and purchase is bound into a deed. Matter This is so that each party gets legal protection for the sale and purchase of land that is done. The deed of binding the sale and purchase of land cannot be used as a basis land registration because basically it is still temporary

12 Nico, 2003, Tanggungjawab Notaris Selaku Pejabat Umum, Center for documentation and Studies Of Business Law, Yogyakarta , p.19 
before the land concerned has completed the buying and selling process, because of the conditions for transitional registration land rights are used for the Sale and Purchase Deed drawn up before the Deed Making Official Soil. ${ }^{13}$

\subsection{Solution to the Making of a Sale and Purchase Binding Agreement (PPJB) in the event of a Dispute}

The authenticity of the deed made by the Notary/PPAT in its manufacture is still guided by the provisions of the applicable laws and regulations. Referring to Article 1868 of the Criminal Code, a deed can be said to be an authentic deed if it is made in the form as regulated in the statutory provisions and made before an authorized party or official in accordance with the location where the deed was made. In addition, the UUJN requires material and formal requirements in making the deed. If these conditions are not met, then it cannot be called an authentic deed, because the authenticity of a deed is lost and the strength of proof will change. ${ }^{14}$

In fact, in making an agreement between the parties in an authentic deed, it is possible for errors to occur, either due to the negligence of the parties or the negligence of the Land Deed Maker Official (abbreviated as PPAT), which has an impact on the deed because it contains formal defects, such as signing the deed which was not performed before the PPAT. PPAT does not read out the contents of the deed, and the supporting documents for making the deed are not valid. This resulted in the denial of the contents of the agreement that had been formulated in an authentic deed. Denial is also possible from a third party who has a legal relationship with the object and suffers a loss due to a deed of sale and purchase. ${ }^{15}$

The binding sale and purchase of land carried out before a notary does not result in the right to the land being transferred at that time from the hands of the land owner to the prospective buyer. Land Deed (PPAT). In practice, the Sale and Purchase Binding Agreement (PPJB) is made before a Notary in order to give more legal force or legal certainty to the agreement made in later proof. ${ }^{16}$

\footnotetext{
${ }^{13}$ Rifki Anggatiartara Akta Pengikatan Jual Beli Tanah Sebelum Dibuatnya Akta Pejabat Pembuat Akta Tanah, Jurnal Notarius, Volume 13 Nomor 2 (2020) E-ISSN:2686-2425 ISSN: 2086-1702, p.892

${ }^{14}$ Vivin Pomantow, "Akibat Hukum Terhadap Akte Otentik Yang Cacat Formil Berdasarkan Pasal 1869 KUHPer", Jurnal LexPrivatum. Vol.VI/No.7/Sept/2018, p.90

${ }^{15}$ Muyassar, Pertanggungjawaban Hukum Notaris Terhadap Pengingkaran Akta Jual Beli Tanah Bersertipikat Pihak Yang Dirugikan, Syiah Kuala Law Journal , Vol. 3, No.1 April 2019, p.149

16 Diah Ayu, Perlindungan Hukum Terhadap Para Pihak Dalam Perjanjian Pengikatan Jual Beli Tanah Yang Dibuat Dibawah Tangan Oleh PT.Cisadane Perdana Di Kota Depok, Journal Diponegoro Law Review , Volume 1, Nomor 2, - 2013, p.3
} 
The solution to the Making of a Sale and Purchase Binding Agreement (PPJB) in the event of a dispute is through deliberation or through the courts.

\section{PPJB dispute resolution solutions outside the court / non-litigation}

Dispute resolution using non-litigation or Alternative Dispute Resolution (ADR) is actually a family dispute resolution model compared to dispute resolution through judicial institutions which tend to be confrontational in nature, taking into account wins and losses and ignores social elements in society that are kinship and mutual cooperation. ${ }^{17}$ Article 1 number 10 of Act No. 30 of 1999 concerning arbitration and alternative dispute resolution explains that alternative dispute resolution is an institution for resolving disputes or differences of opinion through procedures agreed upon by the parties, namely settlement out of court by means of consultation, negotiation, mediation, conciliation, or expert judgment. Land dispute resolution does not always have to be done through a judicial process. ${ }^{18}$ Based on Act No. 30 of 1999, Dispute Settlement can be done through:

\section{a. Deliberation (Negotiation)}

Deliberation or negotiation is a form of dispute resolution outside the court which is carried out by the disputing parties themselves or by their proxies, without assistance from other parties, by means of deliberation or negotiation to find a solution that is considered fair between the parties. ${ }^{19}$

b. Conciliation

Conciliation is the main form of controlling social conflict. This control is realized through certain institutions that allow the growth of patterns of discussion and decision making. In the form of conciliation, land conflicts are resolved through parliament, where both parties discuss and debate openly to reach an agreement. Conciliation is the resolution of conflicts, including land conflicts, which are mediated by one or more neutral conciliators chosen by agreement of the parties.

c. Mediation

Mediation is the control of conflict disputes (land) which is carried out by making a consensus between two conflicting parties to find a neutral third party as a mediator in resolving disputes or conflicts. ${ }^{20} \mathrm{~A}$ third party who helps resolve the dispute with a mediator. The mediator does not have the authority to give a decision on the dispute, but only serves to assist and find a solution to the disputing parties. ${ }^{21}$

d. Arbitration

\footnotetext{
${ }^{17}$ Bernhard Limbong, op.cit, p. 126

${ }^{18}$ Article 1 of Act No. 9 of 2004

${ }^{19}$ Bernhard Limbong, op.cit, p. 134

${ }^{20}$ Ibid, p. 136

${ }^{21}$ Munir Fuady, 2000, Arbitrase Nasional, Alternatif Penyelesaian Sengketa Bisniss, Citra Aditya Bakti, Bandung, p. 47
} 
Arbitration is the control of a conflict or dispute that is carried out by means of the two conflicting parties agreeing to accept or being forced to have a third party present who will make a decision for them in resolving the dispute or conflict. In arbitration settlement, both parties agree to get a legal decision as a way out for conflicts or disputes that occur between the parties. The role of resolving conflicts or disputes is an arbitrator or a panel of arbitrators. ${ }^{22}$

\section{PPJB dispute resolution through the Courts}

Settlement through the judiciary is carried out if the deliberation efforts are not reached, then the settlement must be through the courts. Settlement of land disputes through the courts often takes a long time. The length of litigation is mostly due to the possibility of litigation in at least 3 to 4 stages. ${ }^{23}$

In Article 53 of Act No. 9 of 2004 concerning arbitration and alternative dispute resolution it is stated that a person or civil legal entity who feels that his interests have been harmed by a State Administrative Decision may file a written lawsuit to the competent court containing a demand that the disputed State Administrative Decision be it is declared null and void, with or without a claim for compensation and/or rehabilitation. ${ }^{24}$ Disputes over land rights, which are often heard in the District Court, are actually the object of the case (objectum litis) in the dispute, not State Administrative Decrees or not certificates of land rights, but the rights or interests of the community that are violated..$^{25}$

In connection with this court decision, the following matters should be considered:

a. The court's decision must expressly order the cancellation of the decision granting the right in question.

b. If there is doubt or an interpretation is needed regarding the intent of the Court's decision, this matter should be consulted with the Head of the National Land Agency. ${ }^{26}$

Legal protection is an action or effort to protect the public from arbitrary actions by authorities that are not in accordance with the rule of law, to create order and peace so as to enable humans to enjoy their dignity as human beings. The importance of the role of the Notary in helping to create legal certainty and protection for the community, is more preventive in nature, or is preventive in nature from the occurrence of legal problems, by issuing an authentic deed made before him related to the legal status, rights and obligations of a person in

\footnotetext{
${ }^{22}$ Bernhard Limbong, op.cit, p. 159

${ }^{23}$ Ibid, p. 123

${ }^{24}$ Article 53 of Act No. 9 of 2004, concerning Arbitration And Alternative Dispute Resolution.

${ }^{25}$ Adrian Sutedi, Op.cit, p. 254

${ }^{26} \mathrm{Ibid}$, p. 256
} 
law, and so on, which serves as the most perfect evidence in the Court, in the event of a dispute over related rights and obligations. ${ }^{27}$

\section{Closing}

The Notary's responsibility in making the sale and purchase binding agreement (PPJB) that he made is If the sale and purchase binding deed of land signed and made by a Notary there is an error, it is not in accordance with the procedure for making it, then the Notary has legal responsibility to whom and to whom. who the deed of sale and purchase agreement is made, and if the Notary is proven to have made a mistake, whether intentional or unintentional, then the legal consequences that arise can be subject to sanctions according to the level of error or mistake in the deed of binding sale and purchase made by a Notary may be subject to sanctions including administrative sanctions. The solution to making a deed of sale and purchase binding agreement (PPJB) in the event of a dispute is through deliberation or through the courts. Settlement of land disputes through the courts often takes a long time.

\section{References}

Journals:

[1] Aulia Gumilang, Tanggung Jawab Notaris Dalam Sengketa Para Pihak Terkait Akta Perjanjian Pengikatan Jual Beli (PPJB) Yang Dibuatnya, Jurnal Cendekia Hukum, Volume 5 Nomor 2, March 2020

[2] D.Y Witanto, 2012, Hukum Acara Mediasi Dalam Perkara Perdata Dilingkungan Peradilan Umum Dan Peradilan Agama Menurut PERMA No. 1 - 2008, Alfbeta, Bandung

[3] Deviana Yuanitasari, The Role of Public Notary in Providing Legal Protection on Standard Contracts for Indonesian Consumers, Sriwijaya Law Review Journal, Vol. 1 Nomor 2 July 2017

[4] Dewi Kurnia Putri, Amin Purnawan, Perbedaan Perjanjian Pengikatan Jual Beli Lunas dengan Perjanjian Pengikatan Jual Beli Tidak Lunas, Jurnal Akta, Vol.4 Nomor 4 December 2017

[5] Diah Ayu, Perlindungan Hukum Terhadap Para Pihak Dalam Perjanjian Pengikatan Jual Beli Tanah Yang Dibuat Dibawah Tangan Oleh PT.Cisadane Perdana Di Kota Depok, Journal Diponegoro Law Review, Volume 1, Nomor 2, - 2013

[6] Muyassar, Pertanggungjawaban Hukum Notaris Terhadap Pengingkaran Akta Jual Beli Tanah Bersertipikat Pihak Yang Dirugikan, Syiah Kuala Law Journal , Vol. 3, No.1 April 2019

\footnotetext{
${ }^{27}$ Aulia Gumilang, Tanggung Jawab Notaris Dalam Sengketa Para Pihak Terkait Akta Perjanjian Pengikatan Jual Beli (PPJB) Yang Dibuatnya, Jurnal Cendekia Hukum, Volume 5 Nomor 2, March 2020, p. 246
} 
[7] Rifki Anggatiartara Akta Pengikatan Jual Beli Tanah Sebelum Dibuatnya Akta Pejabat Pembuat Akta Tanah, Jurnal Notarius, Volume 13 Nomor 2 (2020) E-ISSN:2686-2425 ISSN: 2086-1702

[8] Vivin Pomantow, "Akibat Hukum Terhadap Akte Otentik Yang Cacat Formil Berdasarkan Pasal 1869 KUHPer", Jurnal LexPrivatum. Vol.VI/No.7/Sept/2018

[9] Wiriya Adhy Utama dan Ghansham Anand, Perlindungan Hukum Terhadap Notaris Pengganti Dalam Pemanggilan Berkaitan dengan Kepentingan Peradilan, Jurnal Panorama Hukum, Volume 3 No.1 - 2018 ISSN : 22664

Books:

[1] Ahmadi Miru, 2013, Hukum Kontrak dan Perancangan Kontrak, Print.1, Ed. 4, Rajawali Pers,Jakarta

[2] Amiruddin, 2012, Pengantar Metode Penelitian Hukum, Jakarta: PT. Raja Grafindo Persada

[3] Bambang Waluyo, 2002, Penelitian Hukum Dalam Praktek. Sinar Grafika, Jakarta

[4] C.S.T. Kansil, 2003, Pokok-Pokok Etika Profesi Hukum, Pradnya Paramita, Jakarta

[5] Dyara Radhite Oryza Fea, 2018, Panduan Mengurus Tanah Rumah dan Perizinannya, Legality, Yogyakarta

[6] Frans Hendra Winarta, 2012, Hukum Penyelesaian Sengketa, Sinar Grafika, Jakarta

[7] Habib Adjie, 2008, Hukum Notaris Indonesia, Refika Aditama, Bandung

[8] Habib Adjie, 2008, Sanksi Perdata dan Administratif Terhadap Notaris sebagai Pejabat Publik, Refika Aditarna, Bandung

[9] Habib Adjie, 2013, Sanksi Perdata dan Administratif Terhadap Notaris sebagai Pejabat Publik, Refika Aditama, Bandung

[10] Henny Tanuwidjaja, 2012, Pranata Hukum Jaminan Utang dan Sejarah Lembaga Hukum Notariat, Refika Aditama,Bandung

[11] Herlina Hasibuan, Analisis Yuridis Penolakan Pembatalan Akta Perjanjian Pengikatan Jual Beli (Ppjb) Hak Atas Tanah Melalui Prosedur Gugatan Ke Pengadilan (Studi Putusan MA No. 3703.K/Pdt/2016), Tesis Fakultas Hukum Universitas Sumatera Utara Medan, 2020

[12] Munir Fuady, 2000, Arbitrase Nasional, Alternatif Penyelesaian Sengketa Bisniss, Citra Aditya Bakti, Bandung

[13] Ngadino, 2019, Ketentuan Umum Tata Cara Pembuatan Dan Pengisian Akta PPAT, UPT Penerbitan Universitas PGRI Semarang Press, Semarang.

[14] Nico, 2003, Tanggungjawab Notaris Selaku Pejabat Umum, Center for documentation and Studies Of Business Law, Yogyakarta 
[15] Ridwan H.R., 2006, Hukum Administrasi Negara, Raja Grafindo Persada, Jakarta

[16] Salim H. S., 2010, Perkembangan Teori Dalam Ilmu Hukum, Rajawali Pers, Jakarta

[17] Salim Hs, 2016, Teknik Pembuatan Akta Satu, Raja Grafindo Persada, Jakarta

[18] Soegianto, 2015, Etika Profesi dan Perlindungan Hukum Bagi Notaris, Farisma Indonesia, Yogyakarta

[19] Soegianto, 2015, Etika Profesi dan Perlindungan Hukum Bagi Notaris, Farisma Indonesia, Yogyakarta

[20] Subekti, 1998,Hukum Perjanjian, Intermasa, Jakarta

[21] Sudikono Mertokusumo, 1998, Hukum Acara Perdata Indonesia, Liberty, Yogyakarta

Regulations:

[1] Act No. 2 of 2014 concerning Amendments to Act No. 30 of 2004 concerning the Position of Notary.

[2] Article 53 of Act No. 9 of 2004, concerning arbitration and alternative dispute resolution.

[3] Presidential Regulation of the Republic of Indonesia Number 17 of 2015 concerning the Ministry of Agrarian Affairs and Spatial Planning 